Wei Zhang*

\title{
The Development of Marxist Shakespearean Criticism in China $^{1}$
}

\begin{abstract}
Chinese Shakespearean criticism from Marxist perspectives is highly original in Chinese Shakespeare studies. Scholars such as Mao Dun, Yang Hui, Zhao Li, Fang Ping, Yang Zhouhan, Bian Zhilin, Meng Xianqiang, Sun Jiaxiu, Zhang Siyang and Wang Yuanhua adopt the basic principles and methods of Marxism to elaborate on Shakespeare's works and have made great achievements. With ideas changed in different political climates, they have engaged in Shakespeare studies for over eight decades since the 1930s. At the beginning of the revolutionary age, they advocated revolutionary literature, followed Russian Shakespearean criticism from the Marxist perspective, and established the mode of class analysis and highlighted realism. Before and after the Cultural Revolution, they were concerned about class, reality and people. They also showed the "left-wing" inclination, taking literature as a tool to serve politics. Since the 1980s, they have been free from politics and entered the pure academic realm, analysing Shakespearean dramas with Marxist aesthetic theories and transforming from sociological criticism to literary criticism.
\end{abstract}

Keywords: China, Marxism, Shakespearean criticism.

Following the steps of the Soviet Union, China started Marxist Shakespeare study in the 1920s. There are ten representative scholars, namely Mao Dun, Yang Hui, Zhao Li, Fang Ping, Yang Zhouhan, Bian Zhilin, Meng Xianqiang, Sun Jiaxiu, Zhang Siyang and Wang Yuanhua. They held unequivocal political stands and developed China's own Marxist Shakespeare study depending on their enthusiasm for Shakespeare and persistent spirit of exploration. However,

Shanghai University, China.

1 This article was previously published in Chinese in the Journal of East China Normal University (Humanities and Social Sciences) 3 (2017): 118-124, with the title "The Development of Shakespearean Criticism from the Marxist Perspective in China.” The present article in Multicultural Shakespeare is an extended version of the previous article, published with the permission of the Editor of the Journal of East China Normal University (Humanities and Social Sciences). 
no one has ever made a systematic study on their theoretical achievements. Taking the theoretical achievements of the above ten scholars as the objects of study, this paper attempts to clarify the development of Marxist Shakespeare study in China, analyze the reasons and elaborate its contributions and inadequacy by comparing with Marxist Shakespeare studies of foreign countries.

\section{The 1930s and 1940s: Highlighted "Revolutionary Nature"}

Chinese Marxist Shakespeare criticism can be traced back to Mao Dun who published three important articles in the 1930s, "Shakespeare and Realism," "Shakespeare's Hamlet" from Translated Western Literary Classics, and "The 375th Anniversary of the Birth of Shakespeare." And there was a minor mention about Shakespeare in the section "classicism" of Mao Dun's 1930 A General Introduction to Western Literature. "Shakespeare and Realism" was published under the name Wei Ming in Studies of the Humanities (Vol. 1, No. 2) on August 20, 1934. The real author was reportedly Mao Dun. The article only contains 1250 Chinese characters and covers three and a half pages. Strictly speaking, it was not a piece of Shakespeare criticism but an introduction of the views raised by the Soviet critic S. Dinamov in his article "More Shakespeareanism" published in Literature and Art News (Moscow, No. 12) on March 11, 1933. It was the first time that Marxist Shakespeare criticism had been introduced to the public: "Marx and Engels believed Shakespeare was a great realist" (Mao 316). Mao Dun also cited Dinamov's conclusions and explained Shakespearization with six straight parallel structures: (1) "we must find the image that's truly alive to represent the development and movement that's under way"; (2) "we must seize today and then look forward to tomorrow"; (3) "we must ascend the apex of modern thought and clarify the concepts of science, knowledge and culture, and the doctrines of Marx, Engels, Lenin and Stalin, so that our thinking won't dry up, so that our works are as clear and content-rich as a living language"; (4) "we must be daredevil fighters of our own class with art as our weapon"; (5) "we must stand at the forefront of life, fighting, creating, working and struggling"; and (6) "we must seek a more powerful new form of artistic creation and abandon the dazzling but empty Art Deco to create works of both ideological and artistic perfection" (Mao 317-318). This was the first emergence of "Shakespearization" in China, one of the most important concepts of the Marxist literary thought. Apparently, this concept had its special significance in the revolutionary period of the Soviet Union, in view of its reality view, developmental view, scientific nature, combativeness and perfection. In the revolutionary years, Mao Dun cited Dinamov's words because it was necessary at that time and because the concept was fully applicable to the revolutionary struggle in China. Shakespearization could therefore be used as 
a programme guiding the Chinese revolutionary literature. However, Marx and Engels did not talk about combativeness in their discussion of "Shakespearization." The characteristic was later added by Dinamov and Mao Dun in consideration of the revolutionary situation in the 1930s, because realism means attention to the objective social reality, namely, the fast-growing revolutionary struggle. As we see, the term "Shakespearization" can produce a different meaning in a specific period and a specific environment. In the revolutionary years, combativeness was highlighted by Mao Dun in light of the situation; in this era of peace, perfection and richness prevailed in place of combativeness.

In 1944, Yang Hui, a modern literary theorist and playwright, translated and published Timon of Athens (Xin Di Press), and wrote the preamble "Shakespeare's Timon of Athens." This long essay (over 10,000 words) was the first essay on Shakespeare study in light of Marxist theory in China. He pointed out that the play

seems to be a philosophical treatise, or a political pamphlet, that uses the form of drama, to utter an angry call and throw a dead cat to the then society, at which point, Yang is no longer a performer showing the ways of the world on the stage, but an agitator running and preaching at the crossroads-he has become a fighter in the true modern sense. (Meng, Selected 70)

This Athenian story had a deep impact on the British society. It was much like stripping and whipping. And what the story whipped was not some social scars but the society itself. (Meng, Selected 72)

By virtue of a series of smart metaphors, Yang Hui shed light upon Shakespeare's criticism of British society. Although not as speculative as Marx's philosophical theory, Yang's analysis also criticized the evil of money.

Both Mao Dun's and Yang Hui's essays were written in the age of revolution. They were deeply influenced by the Soviet Union's study. In that life-and-death wartime, everyone's nerves were on edge. When appreciating Shakespeare's works, they were sensitive to the parts about life struggle and fight and their articles were full of "the smell of gunpowder." It is consistent with the then revolutionary culture. In the course of the new democratic revolution, in order to build a new cultural system and establish new literary views and new creation methods for the revolution, some Chinese scholars tried to draw spirit and ideological essence from Shakespeare's works. By adopting indirect methods, they firstly introduced the Shakespeare study of the Soviet Union, and then made their own analyses and discussions for Chinese revolution and life. 


\section{Around the Cultural Revolution: Consideration about Class Nature, Reality and Popularity}

Around the Cultural Revolution (the 1950s-1960s), class struggle was still serious in China. "Political situation decides the direction of Shakespeare study. The theories and practices of class struggle extension made most Shakespeare studies in this period focus on class" (Li Weimin 311). During the Cultural Revolution, Shakespeare was defined as a bourgeois writer, so that the publication of The Complete Works of William Shakespeare also halted. Fortunately, there was still some research left, mostly Zhao Li's articles. In the preface to the 1963 Shakespeare (Part I \& Part II) of "Selected Foreign Literature Research Data (First Draft)," Zhao referred to Shakespeare as "an idealistic realist writer" and put him at "the position of advanced bourgeois humanism” (qtd. Li Weimin 312), giving him a class status. At the same time, Zhao also identified and criticized Shakespeare's bourgeois ideology, saying "Shakespeare's thought is based on the theory of human nature that often gets him into the absurdity of moral instruction and moral forgiveness, into the kingdom of idealism faraway from reality, in the face of severe sharp social conflicts, so his thought has a contradiction and this contradiction exactly reflects that of reality" (qtd. Li Weimin 315). There was also a change in Zhao's understanding during his decades of Shakespeare studies. At first, he borrowed the Soviet model of Shakespeare criticism and mostly adopted sociological criticism to analyse the historical background to Shakespeare's plays. Later, he revised many of his early one-sided understandings in "Shakespeare's Characters and Characterization" and other papers. In them, Zhao gave objective judgments rather than subjective assumptions of Shakespeare's characters according to the stories and their artistic presentation. Little trace of the Soviet model was found in Zhao's late works.

In the Cultural Revolution, Shakespeare study basically had no progress in China. After the Cultural Revolution, literary studies revitalized. Some translators and scholars who love Shakespeare's works gradually got rid of the Soviet model and attempted to establish a Marxist Shakespeare study with Chinese characteristics.

Fang Ping, best remembered as the chief editor and translator of The Complete Works of Shakespeare, had been devoted to translating and researching Shakespeare's plays for 60 years. All his researches were included in his book Our Friend Shakespeare that contains 1978-1982 papers about realist ideas. One of these papers, "The Flavor of Life and Reality in The Merry Wives of Windsor," began with words in the letter from Engels to Marx, in praise of the enormous flavour of life and reality that the play has compared with all other German literary works. Then with a neat twist, Fang exposed and criticized the slanderous comment "a pile of rubble" (Fang, Our Friend 2) that was made by the "Gang of Four" and particularly Yao Wenyuan about the "peaks" (Fang, 
Our Friend 2) of Western literature including Shakespeare. Fang Ping added, this play is a most realistic one and only in this play, lively British citizens and their families appeared on the stage as the leading characters, to show the audience their active attitudes and their family stories.

What the comedy exposed and satirized hasn't been actually gone. In our socialist society, for instance, arranged marriage and mercenary marriage should have long been a historical phenomenon. And yet we are still in a transition period of the new mingled with the old. As long as there is still the use of material and money as the cornerstone of marriage, as the first prerequisite for making friends and having a relationship, the nearly four hundred-year-old comedy hasn't actually lost its satirical and realistic significance. (Fang, Our Friend 22)

As we see, Fang Ping's literary criticism is carried out within the framework of Marxism, when the mission was still about the revolution, so literature was closely related with real life, which is also a typical paradigm of Marxist thought and research. Fang Ping consciously revealed the realistic significance of the play at the present time and displayed the aesthetic mirror of social function of literature.

In addition to Mao Dun's view of Shakespearization, Fang Ping also gave his explanation in his article "What is Shakespearization" with two arguments: first is the realistic creation (Fang, Our Friend 266), which is consistent with Mao's view; second is the integration of playwrights and their characters (Fang, Our Friend 275). According to Fang, Shakespearization should be regarded as an artistic technique, an artistic lever to balance the relationship between playwrights and their characters, so as to achieve a perfect integration between the two (Fang, Our Friend 278). Shakespeare's characters are not only inherently independent but inevitably with the marks of Shakespeare. The second argument was Fang's unique insight as a translator and poet. It has not been found in Marxist propositions. And it is different from Dinamov's interpretation of Shakespearization both in angle and content. Fang's contribution to Shakespeare studies is also reflected in his emphasis on the aesthetic education function of Shakespeare's works. Thanks to his work, Shakespeare's artistic charm has been lifted to the level of aesthetic education, the height of moral education (Fang, Our Friend 299). And this is in line with the Marxist view of aesthetic education that advocates aesthetic education, notes the relationship between aesthetic education and social progress, and underlines the huge role that aesthetic education plays in people's growth and quality optimization.

There was an ideological change in Fang Ping's Shakespeare studies. Unavoidably, his early studies were subject to the political environment. For this, Fang Ping said, 
Critics then didn't have the right to think independently in that climate of political repression, so we could only rest content with that external research model, framing each work with the same historical background. Instead of making a specific analysis, we made explaining the forms of class struggle a top priority in literary criticism. (Fang, "The Explorer," 109)

The Cultural Revolution also left a lasting aftertaste in Fang's early concepts, words and sentences. Later, after the 80s, he broke away from the political context and the class struggle theory, and interpreted Shakespeare's works from a human and aesthetic point of view. He also reflected, "I had some of my views expressed in the article 'On Shylock,' but I wrote it in a wrong way. I failed to discuss Shakespeare's plays from the standpoint of the plays. Many of my discussions were based on political concepts.... I should stop writing such articles as 'On Shylock'” (Fang, Our Friend 354-356). These words demonstrate Fang's serious attitude as a scholar as well as his courage to reflect on himself and seek the truth.

The biggest contribution that Yang Zhouhan made to Shakespeare studies was his compilation of The Corpus of Shakespeare Criticism (Part I and Part II), which contains six articles on Marxist Shakespeare criticism by Caudwell, Brecht, Lukacs and Anikst. According to Yang, the Soviet studies had yielded the highest results since the beginning of Marxist Shakespeare criticism in the 1920s and 1930s, but there was a "left-leaning" and "exaggerating" tendency in the Soviet Shakespeare criticism. In this regard, he approved the views of the American scholar Annette Rubinstein

We should study Shakespeare's works by associating them with the social and political struggle of Shakespeare's time, with Shakespeare's objection to feudal civil war and support for national unity, and with Shakespeare's political and social philosophies on the monarch's duties and inheritance, relationship between personal ambition and politics, relationship between religion and politics, etc. (Yang, The Corpus 15)

So Yang's views of Marxist Shakespeare criticism can be summarized as follows: (1) dialectical thought, e.g. colonialism is only one of the issues reflected in The Tempest; (2) objectivity and impartiality, e.g. Shakespeare cannot be seen as a pure optimist; (3) consistent use of the concept "people" (which refers to the working masses in Yang's view); (4) Shakespeare's plays are a combination of realism and romanticism; (5) restoration of the truth and adherence to the materialistic approach to research, rather than the use of some contemporary philosophical and political ideas in place of Shakespeare's (Yang, The Corpus 14). It is worth noting that after all these analyses, Yang also thought about the future of Shakespeare criticism: "Shakespeare studies have been flourishing and have yielded many results with tons of articles published, 
but where it goes in the future remains to be solved" (Yang, The Corpus 17). His broad dialectical view provided a glimpse of "other Marxism-guided Shakespeare criticism than the Soviet one, which seems unfamiliar to us, but from which we may learn something, as rough rocks from other hills can be used for polishing jade" (Yang, The Corpus 17). And this is precisely why Yang decided to compile The Corpus of Shakespeare Criticism. Yang was also quite optimistic about Anglo-American Marxist Shakespeare criticism. He suggested we should introduce those exotic ideas since they broke the monopoly of bourgeois Shakespeare criticism that had lasted two or three centuries. The Anglo-American Marxist Shakespeare criticism has many new perspectives, approaches and discoveries for us to look out the window into a wider Shakespearean world. Yang's suggestion showed a new development path for Chinese Shakespeare studies.

Another influential translator and critic of Shakespeare's plays is Bian Zhilin, who also underwent a change in thinking. In Li Weimin's words, "There was actually a change in Bian's overall view of Shakespeare and his plays, namely, his Shakespeare thought and concept, but what remained unchanged was his belief that Shakespeare's plays reflected the classes and their struggle to a considerable extent" (Li Weimin 267). Bian's masterpiece Towards a New Appraisal of Shakespearean Tragedy brings together all the papers, preambles and translation criticism published from 1955 to 1985. The book bears the marks of all the periods due to a long-time span for writing. Its first article, "On Hamlet," begins:

If we want to conduct scientific research by adopting the standpoints, views and approaches of dialectical and historical materialism, we need to first get a panoramic view.... In no case will we metaphysically turn a typical living character created by a classical writer into a dead image pinned to a textbook. Such a typical character can be creatively understood in a panoramic view with its initiative by people of all ages for them to learn its everlasting educational meaning. (Bian 8; 9)

In Bian's eyes, typicality, popularity and realism are the three most critical things in Hamlet. In terms of popularity, Shakespeare came from a rural town and retired to his hometown living his later life as an ordinary citizen; his contact with people from all social strata, including apprentices, sailors, young students and nobles, during his stay in London, and his apparent subjective efforts, eventually contributed to his deeply popular and realistic creation. Shakespeare demonstrated his love of people in his works as well as his knowledge of their power, but he did not trust their collective action due to class and historical restrictions. The ideal of harmony cannot be achieved by means of collective action because it can easily become blind and violent action at the 
hand of a few careerists. Here, Bian's "people" shares the same meaning as Yang's, namely, the working masses. Against Shakespeare, however, Bian Zhilin advocated mass rebellion and people's revolution for the ideal of harmony.

Zhao Li, Fang Ping, Yang Zhouhan and Bian Zhilin elaborated class nature, realism and affinity to the people in their works and articles from time to time. It is because of the then political ideology deep in their minds. On the one hand, the ideology helped the scholars make deep reflections on the perspective of social significance. On the other hand, it confined the scholars' thoughts. Just like a kite, the scholars were drawn by an invisible political line. As a result, they could not fly their artistic imaginations freely.

\section{Since the Reform and Opening-up: Aesthetic and Literary Interpretation}

After a radical, one-sided and extreme era, Chinese Marxist Shakespeare criticism came to a mild and fair stage. Aesthetics and literature and art were the key words of China's Marxist Shakespeare study during this time. The scholars started to collect relevant materials and made aesthetic analysis. Their studies gradually moved from outside of Shakespeare's works (historical background) to inside. Sun Jiaxiu, Meng Xianqiang and Zhang Siyang were the representatives of rational Shakespeare study.

Among the outstanding works of the reform and opening-up period were Sun Jiaxiu's 1981 Marx, Engels and Shakespeare's Plays and Meng Xianqiang's 1984 Marx, Engels and Shakespeare. It was really not easy for the two to find out the words about Shakespeare in the myriad of works of Marx and Engels. According to their statistics, there are a total of 189 references to Shakespeare in their writings. The largest difference between the two books is that Sun only excerpted relevant words without comment while Meng added the original stories and characters of Shakespeare's plays as well as historical backgrounds and meanings of the references made by Marx and Engels after each quote from their writings. The latter's work has greatly helped with readers' understanding. But the two scholars both have provided a significant introduction to Marx's and Engels' Shakespeare criticism.

Sun Jiaxiu, who had studied drama at an American university, suffered a lot during the Cultural Revolution, but her love for Shakespeare studies never changed. Sun Jiaxiu "closely combined pure academic literature study with study of stage performance of Shakespeare's plays" (Li Weimin 220). She was also noted for "Opinions on 'Shakespeare's Plays and Peking Opera,"” "Criticism on Shakespeare's The Tempest," "Investigation of Four Tragedies by Shakespeare," "Shakespeare's Glossary," and "Shakespeare and Modern 
Western Plays.” She held that taking Marxism as the guidance does not mean simply interpreting the works with several words and sentences of Marx, but analysing Shakespeare's plays with Marxist principles of aesthetics. She paid close attention to the relation between Shakespeare's plays and background of the age, and "tried to find deep-seated, essential or general significances from main ideas, figures, historical background and other elements of the plays and elaborate the root causes of the change of Shakespeare's creative thoughts dialectically and historically” (Meng, Yearbook 289). Sun Jiaxiu made a great contribution to the progress of China's Marxist Shakespeare study.

Meng Xianqiang was a productive writer. His Shakespeare criticism works include Pansy, Shakespeare Studies in China: A Brief History, Selected Chinese Criticism of Shakespeare in China, Chinese Shakespeare Yearbook, Shakespeare's Triple Play, Shakespeare in Our Age, and over 60 papers. Gu Zhengkun referred to him as "a rare noble master of Shakespeare studies" (Yang and Yin 22), and Yang Lingui hailed him as "guider of Chinese Shakespeare studies to the world" (Yang and Yin cover). Speaking of Meng Xianqiang's Marxist Shakespeare study, the most representative work must be Pansies: Decoding Hamlet. He clearly expressed his opinion in the introduction. "The author presents some new theoretical concepts in this book in light of the basic theories of Marxist aesthetics and traditional literary study with the guidance of epistemology and methodology of dialectical materialism” (Meng, Pansies 10). Yang Lingui pointed out that on his study of Hamlet, Meng "broke the role identity with his research object, went through the mists into the work, and then walked out of the work to examine the complexity of human nature in the context of the era" (Yang and Yin 10). Meng thought that firstly, the humanistic spirit in Hamlet was consistent with Marxist humanism (Meng, Pansies 79); secondly, the fighting spirit in this play reflected law of the unity of opposites. The true, the good and the beautiful represented by Hamlet made an arduous fight with the false, the bad and the ugly represented by Claudius (Meng, Pansies 79); thirdly, this play demonstrated suspicion and rationality, the philosophical spirits of the Renaissance. Hamlet can be said a thinker (Meng, Pansies 83-84); fourth, there are many monologues in this play, which reflected the spirit of introspection (Meng, Pansies 88-89); fifth, by making the essential attribute of the stage into "epitome of the time" (Meng, Pansies 92). Shakespeare highlighted realism of drama aesthetics in this play.

An Introduction to Shakespeare (Volumes 1 and 2) written by Zhang Siyang et al. was praised as "the first work in China making a systematic and comprehensive study of Shakespeare's works in light of Marxist views” by Meng Xianqiang (Meng, Brief History 211). A chapter specially discussed "Marx and Shakespeare" (Zhang, Xu, and Zhang 452-475). Focusing on topics like "money and Timon," "Shylock's pound of flesh," "human alienation and Falstaff," "Marxist quotation art," "Marxist Shakespeare criticism" and so on, 
Zhang Siyang concisely and accurately summarized the harmonious and complementary relation between Marxism and Shakespeare's works. "Every sentence, even the most unimportant ones in Shakespeare's works will have their semantic scopes enlarged and meaning deepened after being quoted by Marx in relevant contexts. Moreover, the original words will be endowed with truthfulness. More importantly, Shakespeare provided examples of the history and early form and trend of capitalist society for Marx's theoretical works as well as lots of concrete arguments for his revolutionary theory. And this precisely epitomizes the combination of theory with practice, of reality with history, of abstraction with concreteness, of politics with literature, and of social science with literary art” (Zhang, Xu, and Zhang 452-453). In other words, Shakespeare and his plays are concrete examples in Marx's abstract philosophical discourse to shed light upon the profound truth. Such a combination is arguably the most perfect combination of literature with philosophy in human history, the highest convergence of the ideas of top masters in the two areas. In Zhang's eyes, Marx was a master of quoting Shakespeare's words to reflect reality. The clever use of those quotes was to sometimes portray the rival's image and sometimes reflect the current situation, as an allusion, metonymy, metaphor, analogy, contrast or reflection, in order to achieve the effects of sarcasm, irony, criticism, etc. This is the art of Marxist quotation. With these concrete examples, Marx saved many explanations. In his article "Reflections on Chinese Shakespeare Studies," Zhang Siyang said, "For Chinese Shakespeare criticism, we shouldn't simply confine Shakespeare's plays to the realist model; nor should we arbitrarily take them as annotations to our various doctrines” (Zhang 3-4). Through a comprehensive and serious study of Shakespeare's plays, Zhang called for intensive reading of the original works and accurate grasp of their implications. As a scholar of real knowledge and deep insight, Zhang Siyang gave an objective, impartial judgment of Shakespeare and his works, setting a good example in both epistemology and methodology and laying a solid foundation for the future development of Chinese Marxist Shakespeare criticism.

Wang Yuanhua had been a loyal Marxist since he joined the Party in 1938. In "Struggle and Pain with the Conscience: Impression of Comrade Zhou Yang," Li Ziyun wrote, "I have heard of Comrade Zhou Yang's praise of Comrade Wang Yuanhua as one of the few scholars in the Party with an intimate knowledge of Marxist literary theory" (3). Wang discovered that dogmatism was the epistemological cause of the Party's long-standing "left-leaning” problem, which substituted concreteness with abstraction, but rationality in its true sense meant going from abstract to concrete and analysing people in a specific historical context rather than just label them as "bourgeois" or "proletarians." As an advocate of intellectuality, he wrote such words in his article "Drafting an Article for Zhou Yang:" "Sensibility, intellectuality and rationality are not only concepts raised by German classical philosophers Kant and Hegel but terms 
frequently used by Marx. Marx's 'from abstract to concrete' in his Preface and Introduction to A Contribution to the Critique of Political Economy precisely clarifies the process of sensible, intellectual and rational knowledge and indicates that is the only correct scientific method" (Wang, Self-Narration 199). Wang was actually not satisfied with defining intellectuality with "the method of explanation" and "the method of presentation" from the postscript of Capital: Critique of Political Economy ( $2^{\text {nd }}$ edition), for he believed that intellectuality worked when an analysing mind made some simple rules. And it is a process "from abstract to concrete." Take for example Marx's study of the capitalist economy: it starts from the abstract essential rule of surplus value and gradually goes into the concrete economic phenomena of profit, interest and rent, thus revealing the law for the operation of the capitalist mode of production as a whole. Wang also participated in Zhou's writing of "Investigation of Some Theoretical Issues of Marxism" and boldly pointed out the Party's "much emphasis on practice and little on theory" (Wang, Self-Narration 200). Later, he was unfortunately involved and wronged in the Anti-Spiritual Pollution Campaign.

Wang Yuanhua studied Shakespeare from the Marxist point of view and his researches are concentrated in the 2008 Interpreting Shakespeare, a revision of Interpretation of Shakespeare's Plays. The book contains translations of articles by Shakespeare critics from Britain, Germany, France and other countries. The translation work was done by him and his wife Zhang Ke. Most of his Speculations essays on Shakespeare were also collected in the preface to and the translator's notes and postscript of Interpreting Shakespeare. In the preface, Wang reviewed his changing feeling for Shakespeare from resistance to admiration due to his changing literary and political views of different periods. Wang did not know about Shakespeare when he was a young man: "I couldn't accept his early modern language expression and I was almost blind to his deep insight into the human soul. But later, I got attracted to Shakespeare as I was inspired by Zhang Ke” (Wang, Interpreting 2).

I think that the best Marxist part with Wang's Shakespeare study is his adherence to Marxist critical spirit and introspective spirit. While criticizing problems with the society and the age, Wang had been inspecting and introspecting himself. "Marxist self-criticism refers to a spirit of self-criticism, self-perfection and self-development formed in the course of the emergence and development of Marxism. It is an important characteristic of Marxist theory that enables the theory to advance with the times and maintain enduring vigour and vitality" (Guo 36). Wang's self-reflection was most conspicuous in his understanding of Hamlet. He read Liang Shiqiu's translation of Hamlet in the early years of the Anti-Japanese War. He wrote an article about Hamlet in the early 1950s. And in the early 60s, Wang took that article as the first part of his Analysis of the Four Tragedies by Shakespeare, arguing “I don't think 
Hamlet was hesitant because he was a coward. It should be because of a series of great changes in his life that came too abruptly to him. The king's sudden death, his mother's remarriage to his uncle, a suspected usurper, and his treacherous uncle's immediate seizure of the throne ... all shattered his peace and quiet life. The fickleness of things, perils of the situation and betrayal of friends were enough to overwhelm a prince who had grown up in clover and yet now found himself beset by traps and could fall into any one of them at any moment. All these sudden changes forced him to suspect, to think. He had to hurry to find the truth behind each change and investigate the causes of them. So, Hamlet grew up into a real adult overnight from an enthusiastic innocent child" (Wang, Interpreting 3-4). But later Wang Yuanhua reflected that his article "Hamlet's Character" overly attributed Hamlet's hesitation to environmental changes out of sympathy for and defence of the character and that Hamlet's hesitation was also due to his internal factors. "In face of environmental challenges, each of us would give a different response partly under the influence of our own character" (Wang, Interpreting 4-5). We are shaped by the environment where we are, but we can go beyond it. In 1955, Wang Yuanhua was put under investigation in isolation as "a counterrevolutionary of Hu Feng's Gang” (Li Ziyun 3). It seemed a political joke to him, since he was so loyal to the Party and was yet slandered as an anti-Party person. "At that spiritual torture, my mind had a big twist. What I used to worship as the good, the sacred, just collapsed in a wink. I felt fear. My entire mind trembled with it. It seemed as if I were abandoned in the boundless wilderness. I was panicky not knowing what to do. It was the most horrible time I had ever had in my entire life" (Wang, Interpreting 14). Idealism suffered a devastating blow, and so did Wang's world view. The blow was given by the then social environment. Wang likened himself to Othello, whose world fell apart in despair at news of Desdemona's betrayal. In this regard, the Taiwan scholar Li Youcheng has a remarkable statement:

We can even conclude an autobiographical interpretation from his preliminary analysis of Hamlet and Othello. It was based on the author's ideas and life experience to echo the reader's thoughts, feelings and state of mind in reading. Things that Wang encountered during his study of Shakespeare certainly reflect the life of frustrations of many Chinese intellectuals in some historical phase. (Li, Youcheng 227)

After all that had happened, Wang Yuanhua became increasingly sympathetic and intimate to Shakespeare. He was excited about Shakespeare's insight into the human soul and human nature:

I no longer mind the early modern language of his plays: those over-elaborate lines of metaphors and puns, those exaggerated traces of dramatic techniques, 
those flaws in form resulting from historical limitations .... What matters is that he depicted the real people and their souls. Isn't that what most matters and what most deserves the reader's repeated appreciation? No one could ensure his work stays the best in form. The best form changes over time, but the best content glitters in the human soul throughout the ages. (Wang, Interpreting 15)

Wang Yuanhua's Marxist criticism is also embodied in his adherence to Marxist "reality view" as the author of Toward the Reality. He admired Shakespeare's superb realistic characterization, saying, "When I read his plays again, what first comes to my mind is his endless ocean of art. I've never seen a writer as energetic as Shakespeare. Shakespeare could present every corner of the world in his works when others could only show one. I have no idea what it takes for him to grasp people's inner secrets that they would never confide even when threatened with the world's severest punishment” (Wang, Interpreting 20). Macbeth, Richard III, Iago, Claudius, Shylock and Edmund are typical examples of Shakespeare's true and profound analysis of human nature. It was the realistic disclosure of the evil side of human nature that endowed his works with enlightening artistic effects.

Into the 90s, Wang Yuanhua came into what Xia Zhongyi called “ideological maturity and academic pureness" (Xia 57) period. As Wang says, "It was then when I started to break away with the longstanding preconceptions and think about things using my mind" (Wang, Diary 528). Looking at Shakespeare from the perspective of academic tradition and literary theory, Wang pointed out, "what Coriolanus said about ancient Roman democracy is still worth learning from today" (Wang, Interpreting 20), although the play was about system drawbacks in ancient Rome. He also argued, "King Lear depicts an imperious and wayward tyrant. Yet, when he surrendered the throne and experienced the sufferings of the world, the sense of human nature was gradually aroused in him" (Wang, Interpreting 21). Wang also compared King Lear with the Chinese play Palace of Eternal Life, as both plays are about one hero undergoing changes in different situations. He was also a fan of Falstaff, the Shakespeare comic character, exclaiming "how come the author could give the ugly, the weak artistic charm and then turn the acid, the bitter into witty humour!" (Wang, Interpreting 303) These words are consistent with Marxist aesthetic view. Marx sang praise to British drama for its "bizarre blend of the noble and humble, the horrible and funny, and the heroic and witty" (Marx 215). Falstaff is the epitome of the humble, funny and witty. Wang's preface to and translator's notes and postscript of Interpreting Shakespeare were completed in a very rational, objective and quiet state, so his Shakespearean thought was concentrated in these writings. The pity is that those are informal essays. Strictly speaking, Wang's Shakespeare critiques cannot be regarded as academic papers. 
If he had some academic papers, Wang would undoubtedly leave us greater results in Shakespeare criticism.

Overall, Wang Yuanhua had made unremitting efforts in Marxist Shakespeare criticism on the levels of realism, idealism, critical spirit, human nature, and reality. His deep reflections amidst the turbulence of different times demonstrated the quality of "being independent of the spiritual order constructed by the situation as modern intellectuals" (Xia 58).

\section{Conclusion}

The aforesaid scholars are just a small share of Chinese Marxist Shakespeare critics. There are also Sun Dayu, Gu Shouchang, Li Funing, Chen Jia, Wu Xinghua, Fang Zhong, Wang Zuoliang, Dai Liuling, Zhu Weizhi, Liu Bingshan and many other influential critics. As the space is limited, I only selected the ten most representative ones. Though they already passed away, their valuable works are the starting points of studies of the after generations. After a deep consideration, I summarized features of China's Marxist Shakespeare study into "two turns" and "three trends." "Two turns" refer to first, gradually turning from relying on the Soviet Union model to independent study and building Marxist Shakespeare study with Chinese characteristics, and second, turning studying from political perspective to the perspectives of aesthetics and literary and art. The studies get more rational, with slavish, fanatical and illiberal components greatly reduced. Shakespeare study marched on the path of academic theory. "Three trends" are first, paying attention to realistic achievements in Shakespeare's plays; and second, highlighting the literary tool theory. Some scholars used sociological critical methods to mainly study the historical background of Shakespeare's plays and the social conflicts and class relations. Their studies reflected and emphasized class and class struggle. Moreover, they regarded Shakespeare's plays as tools serving for politics. And third, studying Shakespeare from the perspective of Marxist theory of literature and art, they pertinently analyse the thoughts and art skills in Shakespeare's plays.

Chinese Marxist Shakespeare criticism focuses on revolutionary, popular, class, humanist, typical, realistic, real and critical levels. The early criticism was simplified and politicized. The later criticism achieved remarkable results with lots of academic theories and books. We should push forward with our Shakespeare studies on the basis of these previous achievements and take the initiative to absorb the quintessence of foreign Marxist Shakespeare studies in order to win a place in the international Marxist Shakespeare criticism. 


\section{WORKS CITED}

Bian, Zhilin. Towards a New Appraisal of Shakespearean Tragedy. Hefei: Anhui Education Press, 2007.

Fang, Ping. "The Explorer of Human Nature: Shakespeare in the Tragedy Period." Foreign Literature Review 1 (1994): 103-110.

Fang, Ping. Our Friend Shakespeare. Chengdu: Sichuan People's Publishing House, 1983.

Guo, Zhenghong. "The Self-Critical Spirit of Marxism and its Contemporary Value." Studies on Marxism 5 (2015): 36-41, 62.

Li, Weimin. Shakespeare Study in China: On Shakespearean Scholars' Thoughts and Theoretical Construction. Chongqing: Chongqing Publishing Group, 2012.

Li, Youcheng. "Wang Yuanhua and Shakespeare Research.” Taipei: Thoughts. 24 (2013).

$\mathrm{Li}$, Ziyun. "Struggle and Pain with the Conscience: Impression of Comrade Zhou Yang." Shanghai: Wenhui Daily, August 31, 1988.

Mao, Dun. The Complete Works of Mao Dun. Vol. 33. Beijing: People's Literature Publishing House, 2001.

Marx, Karl. The Complete Works of Marx and Engels XIII. Trans. Central Compilation \& Translation Bureau. Beijing: People's Publishing House, 1998.

Meng, Xianqiang. Pansies: Decoding Shakespeare. Beijing: Commercial Press, 2007.

- Shakespeare Studies in China: A Brief History. Changchun: Northeast Normal University Press, 2014.

— Press, 2014.

— University Press, 2014.

Wang, Yuanhua. Diary for the 1990s. Hangzhou: Zhejiang People’s Publishing House, 2001.

- Interpreting Shakespeare. Shanghai: Shanghai Bookstore Publishing House, 2008.

- Self-Narration in Qing Garden. Guilin: Guangxi Normal University Press, 2001.

Xia, Zhongyi. Interpretation of Wang Yuanhua. Shanghai: Wenhui Press, 2004.

Yang, Lingui, and Yin Yao, eds. Shakespeare Studies in China: Essays in Memory of Meng Xianqiang. Changchun: Northeast Normal University Press, 2012.

Yang, Zhouhan, ed. The Corpus of Shakespeare Criticism (II). Beijing: China Social Science Publishing House, 1981.

Zhang, Siyang. Shakespeare's Triple Plays. Changchun: Northeast Normal University Press, 1988.

Zhang, Siyang, Xu Bin, and Zhang Xiaoyang. An Introduction to Shakespeare (II). Beijing: China Theater Press, 1989. 